\title{
IDOSOS ATENDIDOS POR UM SERVIÇO AEROMÉDICO: BREVE CARACTERIZAÇÃO
}

\author{
Vivian Carla de Castro"; Jéssica Teixeira Lourenço²; Larissa Pereira Simardi³; Nelson \\ Augusto Mendes ${ }^{4}$
}

\section{RESUMO}

Sabendo da influência que as alterações fisiológicas provocadas pelo processo de envelhecimento possuem na resposta do organismo às injúrias, e considerando que a população idosa tem crescido em grandes proporcções, este estudo objetivou caracterizar os atendimentos realizados a idosos pelo serviço aeromédico de uma Regional de Saúde do Estado do Paraná. Tratou-se de uma pesquisa quantitativa, descritiva e transversal, do tipo documental retrospectiva. Os dados foram coletados em agosto de 2019, a partir dos registros digitais das ocorrências com idosos atendidas pelo serviço aeromédico no período de novembro de 2016 a maio de 2019, e analisados descritivamente. Foi contabilizado um total de 494 ocorrências para atendimento e/ou transporte de idosos com média de 72 anos, sendo que $59,3 \%$ deles eram do sexo masculino. O tempo médio de vôo de todas as ocorrências foi de uma hora e os atendimentos foram mais frequentes às terças-feiras $(18,8 \%)$ e no mês de setembro (10,3\%). As principais hipóteses diagnósticas levantadas foram: cardiopatias $(42,9 \%)$, acidente vascular encefálico (AVE) $(14,4 \%)$, trauma $(9,9 \%)$, e parada cardiorrespiratória (PCR) $(5,5 \%)$. Os achados do estudo poderão auxiliar tanto em iniciativas para melhor qualificação dos profissionais que atuam no serviço, quanto no fomento de novos estudos para realizar comparações e novas discussões.

Palavras-chave: Resgate Aeromédico, Idoso, Serviços Médicos de Emergência.

\section{INTRODUÇÃO}

Em diversos países, o serviço aeromédico é utilizado para oferecer cuidados pré-hospitalares avançados a pacientes em situações de emergência e transporte mais rápido para o centro especializado de referência. Tanto para condições traumáticas quanto clínicas essa modalidade já mostrou evidências de benefício aos pacientes (ANDREW et al., 2015). No Brasil, a modalidade aeromédica passou a ganhar força após a implantação da Política Nacional de Atendimento às Urgências, 1Doutora em Enfermagem. Enfermeira do Serviço Aeromédico do SAMU Regional Norte Novo, Maringá-PR. Professora do curso de Medicina do Centro Universitário Integrado, Campo Mourão-PR. ${ }^{2}$ Especialista e Urgência e Emergência. Enfermeira do Serviço Aeromédico do SAMU Regional Norte Novo, Maringá-PR.

${ }^{3}$ Enfermeira na Unimed Maringá-PR. Pós-Graduanda em Urgência e Emergência do Centro Universitário UniCesumar, Maringá-PR.

${ }^{4}$ Enfermeiro.Coordenador da Pós Graduação de Transporte Aeromédico e Medicina Aeroespacial da Faculdade CENSUPEG, Curitiba-PR 


\section{CON

tornando-se componente móvel avançado da rede de atendimento às urgências (CAMILLO; MATSUDA, 2017). Os helicópteros, considerados transportes do Tipo E, são aeronaves de asa rotativa destinadas ao transporte inter-hospitalar de pacientes e para missões de resgate, dotadas de equipamentos médicos homologados pela Agência Nacional de Aviação Civil (ANAC) (SCHWEITZER et al., 2017).

Embora o serviço aeromédico abranja indivíduos de todas as faixas etárias, destaca-se, no presente estudo, sua utilização como recurso para assistência à saúde da pessoa idosa. Considerando que as alterações fisiológicas provocadas pelo processo de envelhecimento influenciam na resposta do organismo às injúrias, tornando os idosos mais sucetíveis a desfechos desfavoráveis e que essa população tem aumentado significativamente em todo o mundo (NASCIMENTO et al. 2018), esta pesquisa teve por objetivo caracterizar os atendimentos realizados a idosos pelo serviço aeromédico de uma Regional de Saúde do Estado do Paraná.

\section{METODOLOGIA}

Tratou-se de uma pesquisa quantitativa, descritiva e transversal, do tipo documental retrospectivo. Os dados foram coletados em agosto de 2019, a partir dos registros digitais das ocorrências com idosos atendidas pelo Serviço de Atendimento Móvel de Urgência (SAMU), modalidade aeromédica, de uma Regional de Saúde do Estado do Paraná. Os critérios de inclusão foram: pessoas com idade igual ou superior a 60 anos, atendidos e/ou transportados pelo helicóptero de suporte avançado de vida da referida unidade do SAMU, no período de novembro de 2016 a maio de 2019 . Foram excluídos os registros em que não houve atendimento de saúde pelo serviço aeromédico. Constituíram as variáveis do estudo: sexo, faixa etária, tempo total de vôo, dia da semana, mês e natureza da ocorrência.

Os dados foram tabulados em planilha do Excel e analisados descritivamente, por meio do cálculo de frequências e percentuais dos atendimentos aos idosos de acordo com as variáveis incluídas. O estudo atende aos preceitos éticos propostos pela Resolução do Conselho Nacional de Saúde (CNS) n466 de 2012.

\section{RESULTADOS E DISCUSSÕES}




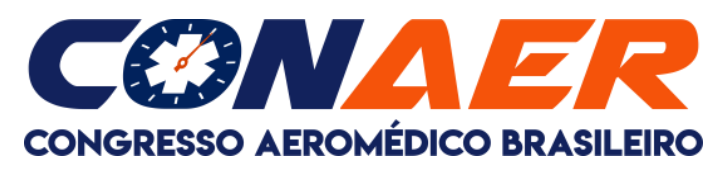

Foi contabilizado um total de 494 ocorrências para atendimento e/ou transporte de idosos, os quais tinham idade entre 60 e 99 anos (média de 72 anos), sendo que $59,3 \%$ eram do sexo masculino, o que corrobora com estudo nacional sobre o atendimento a idosos pelo serviço aeromédico (NASCIMENTO et al., 2018).

O tempo médio de vôo de todas as ocorrências foi de uma hora, variando de cinco minutos até três horas e meia. Quanto aos dias da semana, os atendimentos aconteceram mais às terças-feiras $(18,8 \%)$ e, em relação aos meses do ano, o mês de setembro apresentou a maior frequência $(10,3 \%)$ de ocorrências direcionadas a idosos. Apesar disso, os resultados não descrevem o predomínio de atendimentos em determinado dia da semana ou mês do ano no serviço em questão, destacando que a população idosa está sujeita a apresentar situações de emergência em qualquer período. Outras regiões, contudo, podem apresentar tendências sazonais, como no caso de estudo realizado em Florianópolis-SC, onde os atendimentos tendem a aumentar nos meses de dezembro a janeiro, quando a cidade recebe muitos turistas (NASCIMENTO et al., 2018).

As principais hipóteses diagnósticas levantadas perfazem mais que $70 \%$ do total dos atendimentos, a saber: cardiopatias (42,9\%), acidente vascular encefálico (AVE) $(14,4 \%)$, trauma (9,9\%), e parada cardiorrespiratória (PCR) $(5,5 \%)$. As demais incluem patologias respiratórias, aneurisma, hemorragia intracraniana e digestiva, crise convulsiva, rebaixamento do nível de consciência, câncer, etc.

As cardiopatias envolvem, entre outros, insuficiência cardíaca congestiva, bloqueios átrio-ventriculares e síndromes coronarianas agudas (SCA), sendo que essas últimas respondem por $71,7 \%$ dessa classe. Entre as SCA, 136 casos foram diagnosticados como infarto agudo do miocárdio (IAM), dos quais, aproximadamente 90\% possuíam supradesnivelamento do segmento ST no eletrocardiograma. Ressalta-se, ainda, que dos 136 idosos com IAM, quatro sofreram PCR durante o atendimento e apresentaram retorno à circulação espontânea após intervenção da equipe. Quanto às demais 27 PCR atendidas pelo serviço aeromédico, 16 evoluíram para óbito. A PCR está associada a altas taxas de morbimortalidade e o sucesso da ressuscitação cardiopulmonar depende da eficiência do atendimento.

Em estudo realizado em Londrina-PR, a prevalência da PCR extra-hospitalar se deu em homens, acima de 60 anos e com doenças cardiovasculares, já a sobrevida foi de 25,1\% (ZANDOMENIGHI; MARTINS, 2018). No presente estudo, nota-se que aproximadamente $40 \%$ das vítimas de PCR atendidas pelo serviço aeromédico 


\section{CONAER

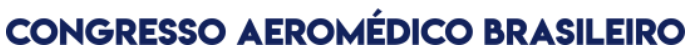

retornaram à circulação espontânea. Acredita-se, portanto, que o emprego de aeronave pode proporcionar o rápido deslocamento de uma equipe de saúde e favorecer a sobrevida das vítimas de IAM e PCR .

Entre os idosos diagnosticados com suspeita de AVE, 71,8\% eram, possivelmente, de origem isquêmica. A trombólise intravenosa com ativador do plasminogênio tecidular recombinante (IV-rtPA) representa um avanço no tratamento do $A V E$ isquêmico, sendo imprescindível a rápida remoção do paciente para um centro de referência. Tendo em vista que a incidência do AVE aumenta exponencialmente com a idade e que esta, isoladamente, não deve representar um critério de exclusão para o tratamento (EIRA et al., 2018), o transporte aéreo desses idosos pode aumentar a sobrevivência e a qualidade de vida.

A terceira hipótese diagnóstica mais comum para os idosos assistidos foi o trauma, sendo a maioria $(38,7 \%)$ proveniente de acidentes de trânsito. Alterações fisiológicas relacionadas ao envelhecimento, presença doença crônica e uso de medicamentos podem predispor os idosos ao trauma, complicar lesões traumáticas e diminuir a capacidade de compensar choque hemorrágico (MCSWAIN; FRAME; SALOMONE, 2016). Considerada a fragilidade do idoso no que tange ao trauma, cabe ressaltar a importância da aeronave não somente nos atendimentos imediatos a essas vítimas, mas também no transporte das mesmas entre instituições, garantindo o acesso mais rápido ao atendimento especializado de referência de forma segura (MCSWAIN; FRAME; SALOMONE, 2016; NASCIMENTO et al., 2018).

\section{CONSIDERAÇÕES FINAIS}

O serviço aeromédico é uma modalidade de assistência em saúde que permite um transporte rápido, eficiente e direcionado ao centro de referência para tratamento definitivo do paciente. Conhecendo as necessidades de saúde específicas da população idosa, acredita-se que o emprego de aeronaves para intervenção da equipe de saúde em situações de emergência pode beneficiar os pacientes. Nesse sentido, o presente estudo permitiu uma breve caracterização dos atendimentos prestados a idosos pelo referido serviço aeromédico, o que poderá auxiliar tanto em iniciativas para melhor qualificação dos profissionais que atuam no serviço, quanto no fomento de novos estudos para comparações e novas discussões. 


\section{CONAER

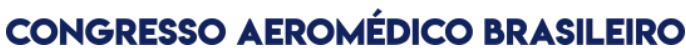

\section{REFERÊNCIAS}

ANDREW E, WIT A, MEADLEY B, COX S, BERNARD S, SMITH, K. Characteristics of Patients Transported by a Paramedic-staffed Helicopter Emergency Medical Service in Victoria, Australia. Prehospital Emergency Care, v.19, n.3, p. 416-424, 2015.

CAMILLO NRS, MATSUDA LM. Transcultural adaptation and validation of the instrument Pittaetool for Brazil. Journal of Nursing UFPE on line, v. 11, n. 11, p. 45184523, 2017.

EIRA, C.; MOTA, A.; SILVÉRIO, R.; MIRANDA, M.; RIBEIRO, P.; GOMES, A., et al. Trombólise Intravenosa no Acidente Vascular Cerebral Isquémico Agudo Depois dos 80 Anos. Medicina Interna, v. 25, n. 3, 2018.

MCSWAIN, E.N.; FRAME, S.; SALOMONE, P.J. PHTLS: PreHospital Trauma Life Support . 8aㅡ ed. Burlington: Jones \& Bartlett Learning; 2016.

NASCIMENTO, K.C. FERNANDES.C.F. GIRONDI, J.B.R. SEBOLD, L.F. HAMMERSCHMIDT, K.S.A. MOREIRA. A.R. Idosos Atendidos em um Serviço Aeromédico. Rev. Bras. Geriatr. Gerontol., v. 21, n.1, p. 82-90, 2018.

SCHWEITZER G, NASCIMENTO ERP, NASCIMENTO KC, MOREIRA AR, AMANTE LN, MALFUSSI LBH. Emergencyinterventions for air medical services trauma victims. Rev. Bras. Enferm., v. 70, n. 1, p. 48-54, 2017.

ZANDOMENIGHI, R. C.; MARTINS, E. A. P. Análise epidemiológica dos atendimentos de parada cardiorrespiratória. Rev enferm UFPE on line, v. 12, n. 7, p.1912-22, 2018. 